\title{
„OPEN FOR CONSERVATION”: LIVE EXPERIENCES
}

\section{COSTANZI Cobau Andreina ${ }^{1}$}

${ }^{1}$ Senior Conservator; CCA, Centro di Conservazione Archeologica di Roma; andreinacostanzicobau@ccaroma.org https://orcid.org/0000-0001-8547-7374

ABSTRACT: The need to show to the public issues related to conservation of cultural properties first became clear in the eighties during the great projects conducted in the Roman forum. Three major conservation innovations were introduced at that time: documentation became part of the contract specifications; consolidation was performed using slaked lime; the worksite scaffolding was opened to non-specialists. The way in which the documentation is realized is an indicator of the quality and professionalism of a program. This should incorporate a communication plan, to promote and raise awareness among the public about the instances related to the conservation of cultural heritage. This article addresses the communication principles applied to conservation interventions.

KEYWORDS:Conservation, communication, documentation, aperto per restauro, open for restoration

The event of a conservation intervention offers opportunities to show and inform the public about the full range of activities for safeguarding cultural heritage. Given this premise, I hope that the „Closed for Restoration" sign will become obsolete, for all of us.

This paper tells the story of worksites open to the public, operated by the Centro di Conservazione Archeologica di Roma (CCA). It's a story that's also my own, since I've worked with this organisation since 1982.

The need to show the public the issues involved in conservation of cultural properties first became clear in the great conservation conducted in the Roman Forum during the 1980s. For us in the CCA, the project for the Arch of Septimius Severus in Rome allowed the introduction of three major conservation innovations: Documentation became part of the contract specifications; consolidations were performed using slaked lime; visits were offered for the non-specialist public. 

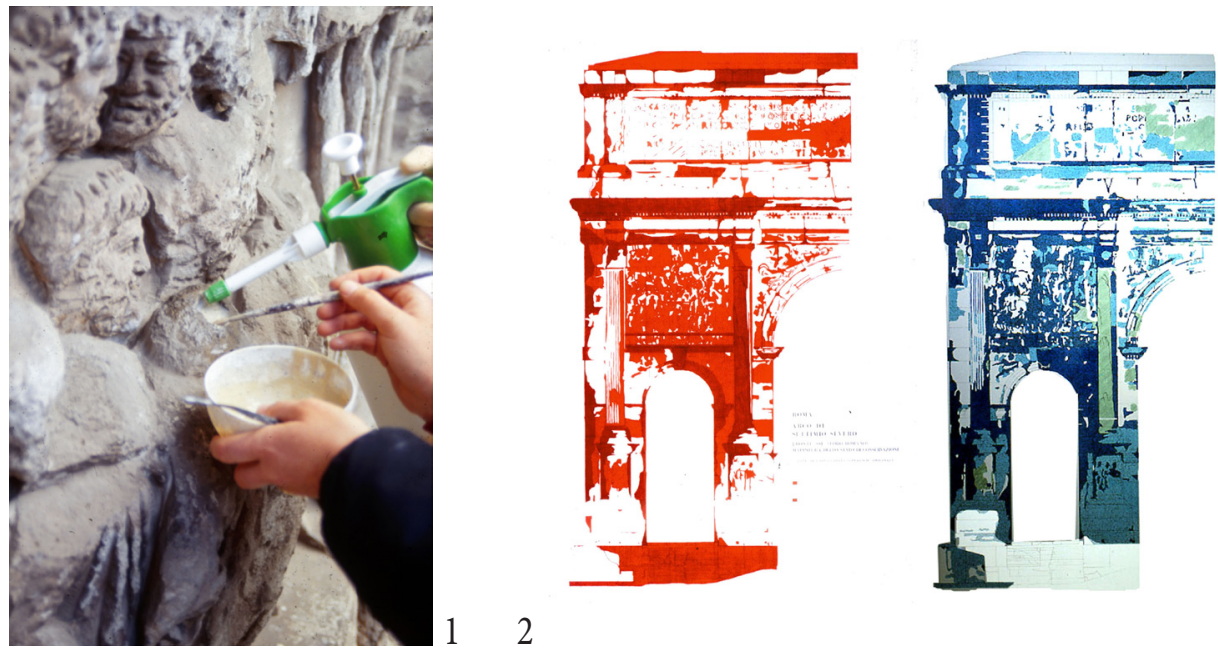

Fig. 1 1980-82, Arch of Septimius Severus in Rome: as a superficial protective a lime wash was use (CCA photo)

Fig. 2 1980-82, Arch of Septimius Severus in Rome: two examples of documentation panel (CCA photo)

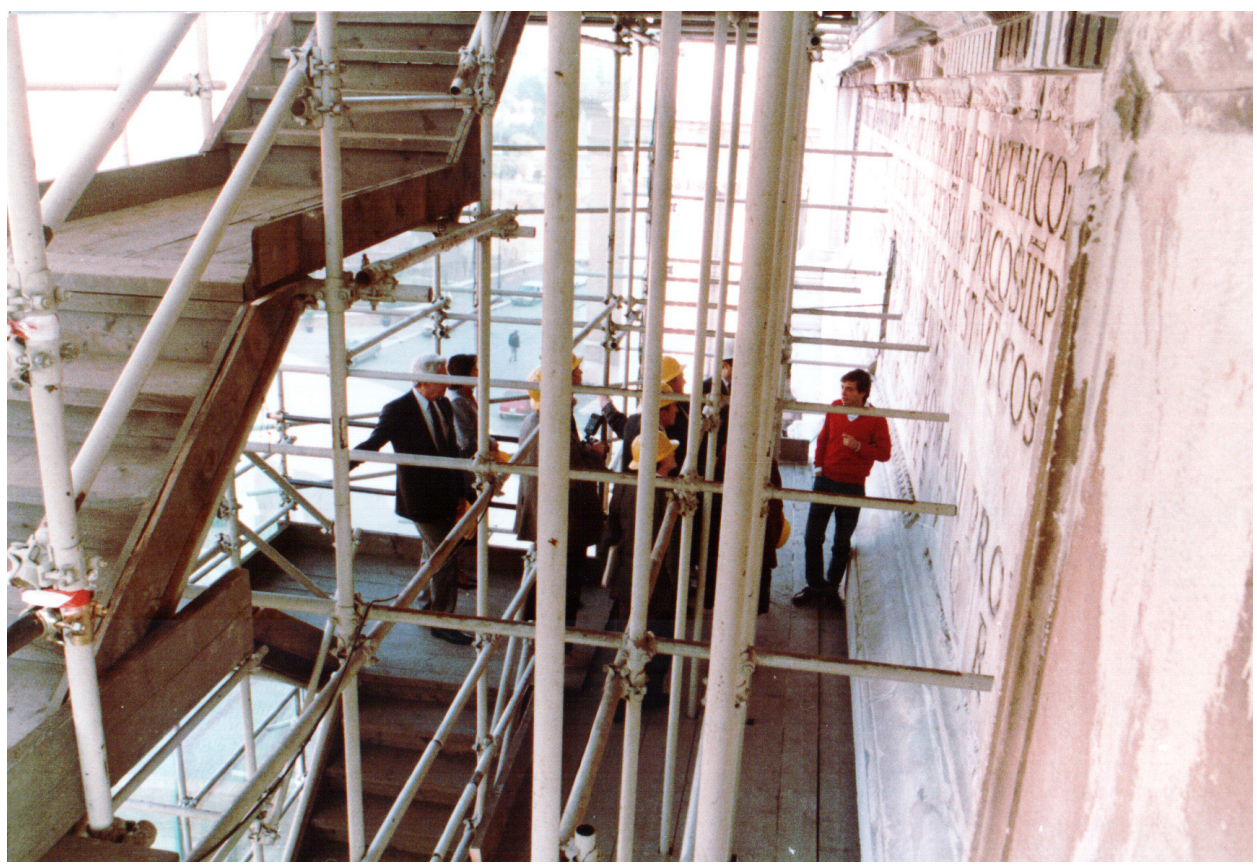

Fig. 3 1980-82, Arch of Septimius Severus in Rome: guided tours were organized bringing visitors on the scaffolding (CCA photo) 
In fact, the worksite hoarding was opened to the broadest possible public.

These new aspects were not independent of one another. Instead they were interconnected and descended from a single unifying philosophy. The insertion of contractual terms requiring documentation arose from our observation of the need to evolve beyond an antiquated vision of conservation-restoration, under which professionals would attempt to keep their ,recipes' hidden. Documentation of a conservation intervention requires that we adhere to a methodology based on a clear and legible scientific approach. Secret recipes have no place in modern interventions. Instead the materials used should be shown and explained to the public. In our case this means choosing of materials from among those used in historic techniques of execution, and proven by time, such as slaked lime. The use of slaked lime in consolidation interventions is based on the principle of using materials compatible with the original ones. The same applies to the use of lime wash as final protection for the surfaces. Although this technique has caused unfavourable reaction from other professionals, such an attitude is largely due to inexperience. Through the choice of an appropriate concentration of lime wash, we obtain optimal protective layer, sufficiently covering to seal any microfractures. Related to these first two innovations was the final one, of showing the worksite activities to the public, including the application of a lime-based protective layer on deteriorated surfaces. Thus, we decided to open the worksite for the Arch of Septimius Severus (Nardi, 1984) to the public, along with other conservation worksites in the Roman Forum. The articles appearing in the newspapers of the day serve as the measure of public reaction, and the success of the initiative.

These conservation projects of the 1980s established a distance from the presentation of conservationrestoration as an activity conducted on the basis of secret recipes, exclusively by experts, far from the public eye. The transformation was enormous. Even though it was not immediately clear, we were seeing the first steps in clarifying the conceptual differences between restoration and conservation, as expressed in our terminology (ICOM-CC, 2008).

In 1990, during conservation of the Capitoline Museums atrium, the CCA decided to maintain access to the entire space. To invite the public in, we painted a hoarding with openings for viewing, and set out signage: by simply walking around, the visitors arrived at the conservators, at work. Our aim was to stimulate the curiousity of individuals approaching the museum entrance, offering a welcome to the worksite in action (La Rocca 1994). Also, on this occasion, the museum visitors were asked to respond to a survey intended to measure their interest in a museum activity that was now carried out in public view, for the first time. 


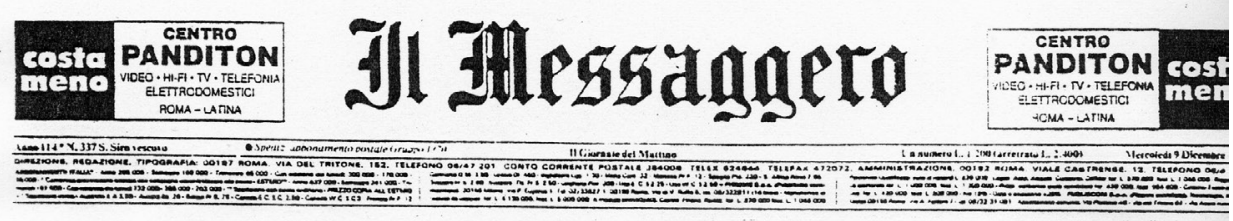

\title{
Per la prima volta in Italia s'interroga il "pubblico dell'arte" Ai Capitolini sondaggio sui restauri
}

\begin{abstract}
Ai Musei capitolini, per la prima volta in Italia, un sondaggio di massa cerchera di capire che cosa il pubblico sa, percepisce e conosce del deterioramento delle opere d'arte e del loro restauro: per due settimane, a partire da oggi, i visitatori che si recheranno ne palazzo realizzato nel 1655 su disegno di Michelangelo saranno invitat a riempire un questionario, $i$ cui risultati potranno indicare quanto il "pubblico dell'arte" conosce del degrado delle opere e del restauro.

L'idea del sondaggio è venuta a Roberto ed Andreina Nardi, che con il loro "Centro di conservazione ar-
\end{abstract}

\begin{abstract}
cheologica", in un anno e mezzo di lavoro, hanno praticamente rimesso a nuovo (ottenendo anche rilevanti risultati scientifici) l'atrio dei Capitolini, che al piano terreno dei musei ospita la più antica raccolta pubblica di sculture classiche. Sotto la supervisione di Marina Mattei, della direzione dei Musei, dieci esperti hanno restaurato tre statue marmoree gigantesche e venti a grandezza naturale, cinque sarcofagi, 260 tra epigrafi e cippi, 2.500 metri quadrati di travertini e intonaci.

A completare l'opera, manca soltanto una statua, ancora annerita dalla pati-
\end{abstract}

na del tempo; e proprio davanti ad es sa sarà distribuito il questionario destinato al pubblico: perché si deteriorano le statue e, dopo il loro restauro, il degrado cesserà? Perché si restaura e chi deve farlo? Che effetto produce l'interyento compiuto, paragonandolo con le condizioni antecedenti ai lavori; l'impegno di un anno e mezzo, di dieci persone, è equo o eccessivo, e come viene giudicata la spesa di sei milioni all'anno per mantenere in buono stato la collezione; e via di questo passo. Sarà interessante esaminare i risultati del sondaggio.

Fig. 49 dic 1994, Il Messaggero, the Rome newspaper: "For the first time in Italy the 'Audience of art' is questioned. At the Capitoline Museum a survey on restoration"

Our intention was to call public attention to a museum activity which until then had always been conducted behind the scenes. There was not a single critical response to the survey questions, and in fact all the responses were enthusiastically approving. With this event, a guiding concept was becoming ever clearer: The public is part of the museum, and those who work in museums must work with the public.

One year later, in 1991, ICCROM added a new statutory mandate: "To support initiatives that increase public awareness of conservation and restoration of cultural property". (de Guichen, 2009) Now, an international organisation recognised the key role of the public in the conservation and cultural production processes. It was at this time that Gaël de Guichen organised the ICCROM „Media Save Art" campaign, a global participation project that marked an epoch. In 1996, Gaël de Guichen received the Keck Award, the IIC's greatest recognition, in consideration of this work.

These first attempts at public involvement in the conservation of our public heritage raised the question of accessibility (Semeraro 2009), but we were still in the years in which our ,only' objective was to capture public attention, in particular concerning a little-known aspect: the fragility of this heritage. In 1997, at Masada, Israel, we developed coloured panels to capture the attention of the tourist visitor, enlivening the monotone desert and offering worksite access. Once again, our observation was confirmed, that people consistently appreciated the possibility of seeing and understanding what once typically invisible activities were. Here, the conservation worksite again emphasised our special message: Masada too was fragile, in fact extremely fragile (Nardi, 2009). 
In 1999, the worksite organised for the „wounded Amazons” brought together two Roman sculptures exhibited in separate institutions: the Capitoline and Montemartini Museums. We publicised this as a unique occasion for a first-person visit to a conservation project, and to see both sculptures together.
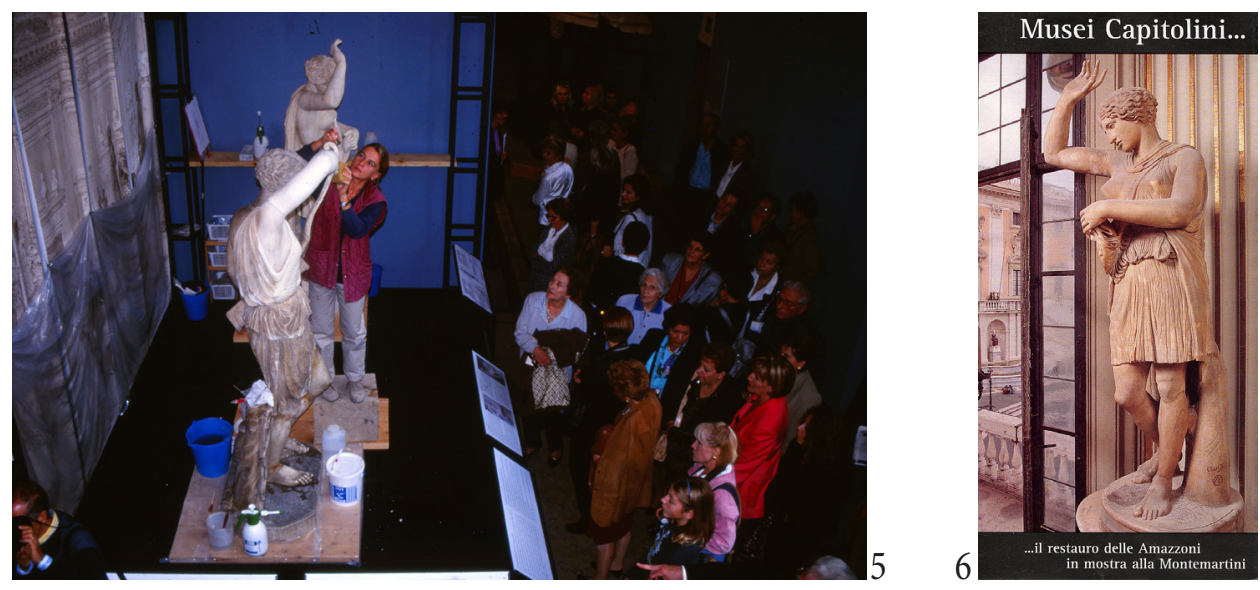

Fig. 5 1997, Wounded Amazons: the Public was able to observe the conservation intervention live (CCA photo)

Fig. 6 1997, Wounded Amazons : the poster advertised the restoration in the exhibition, not only the sculptures!

The comments from the public gradually brought us to realise how much more our conservation projects could offer. Visitors stayed with us for hours, to watch, comment, ask questions (de Guichen, 2009). We too were gratified, to be able to chat, about how we'd become conservator-restorers, about the methods we use. But the most frequent questions tended in other directions: „Would the Amazons return like new?”; and „How long does a restoration last?” Our visitors still viewed the conservation intervention as a kind of plastic surgery: a treatment to restore beauty, to return to a prior state. We realised that we had to communicate a different message.

By the time we presented our next project to the Rome Superintendency and Capitoline Museums, we had come to realise the need to truly involve the visitors, making them an active part of the process. The year was 2000, and the restoration work was for the marble centaurs of Hadrian's Villa. This was the launch of the Aperto per restauro (Open for restoration) project (Costanzi Cobau, 2003).

Opening a conservation project to the public requires a specific plan. It creates an interaction between museum and visitors: between supplier and consumer. Visitors welcome the chance to interact with the conservator and open up to commenting on the museum and on other heritage management systems. The museum or system can draw on this to better understand how to respond to user interests. But the conservation lab, now part of the museum presentation, must provide effective systems for visitor communication. We have to explain what we're doing, in clear, non-specialist terms. We have to keep informed of overall operations, not just our own individual activity. The laboratory walls expand, and all professionals become part of a team.

In the case of Aperto per restauro, conservator/restorers assumed an important role in making objects accessible, by promoting and guiding hands-on interaction. We organised guided visits for 
blind and partially sighted people. Indeed, accessibility is a key factor in successful „conservation communications".

We also organised two public contests, for best written and graphic presentations concerning the heritage conservation. The whole project received the Keck Award in 2004.

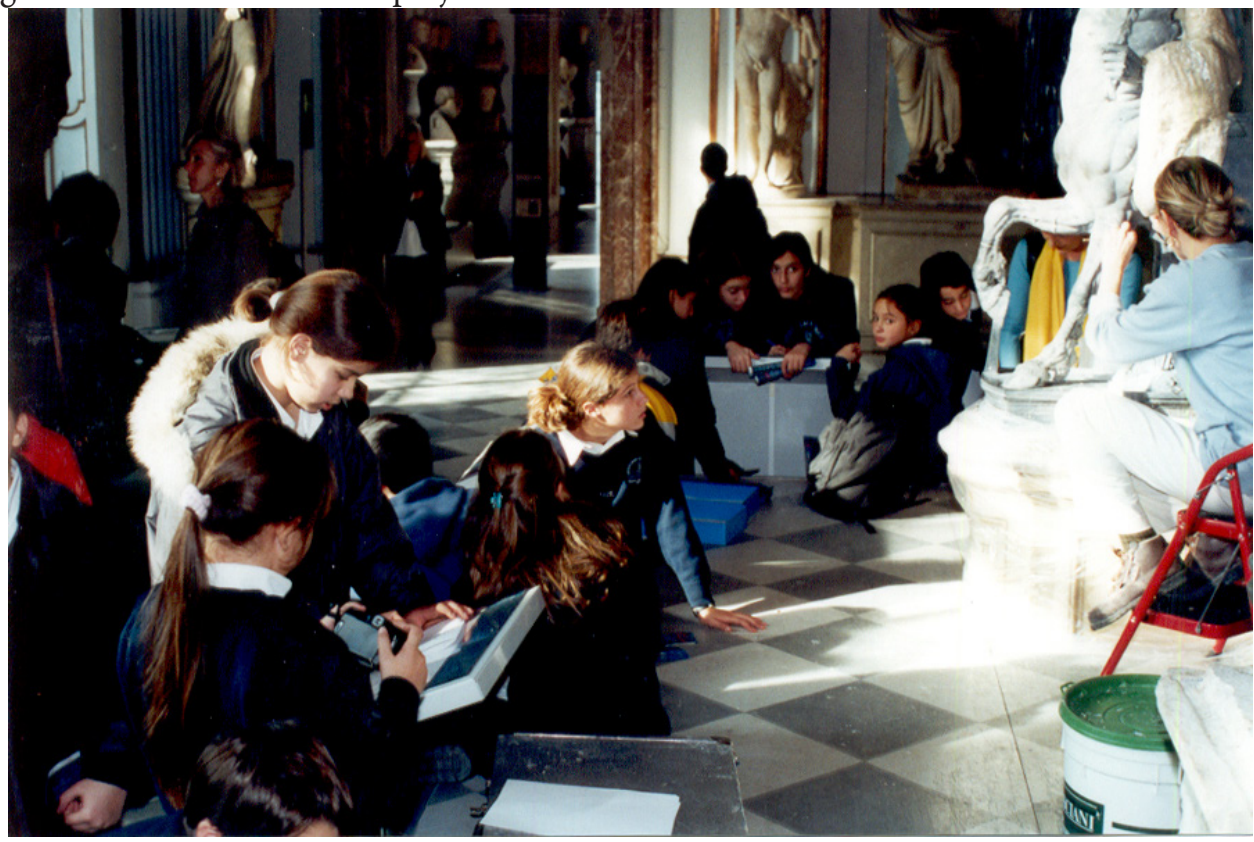

Fig. 7 2000-2002: Conservation Project "Aperto per Restauro", Centauri Capitolini. For the first time the schoolchildren were asked to take part in a competition, taking the conservation project as their starting point (CCA photo)

On the occasion of the closing ceremony, an exhibition of all the graphic submissions was organized, and the Mayor of Rome, Walter Veltroni, awarded the prizes.

By this time, we had come to understand the error of our own professionals in feeling that conservation of public heritage is poorly understood and supported (Pye, 2001) within the other heritage professions, and by the public. It is true that environmental conservation arouses strong feelings and has been effectively communicated. But conservation of cultural heritage can do equally well, provided we take advantage of the levers' available to us.

In 1975, an excavation at Monte Prama, on the east coast of Sardinia, brought to light exceptional materials (Tronchetti, 2005). Newspapers splashed the findings on the front page; interest is high, and there is talk of conservation and display. Months, then years pass, and complaints began to surface, with overtones of Sardinian independence. In local opinion, the materials awaiting restoration have been intentionally hidden away by the Italian Ministry of Cultural Heritage. A movement against state institutions gains ground: The Monte Prama sculptures are suddenly a metaphor for the island of Sardinia, suppressed by mainland Italy.

The materials amounted to more than five thousand fragments: parts of architectural models, and especially of sculptures of warriors - archers with bows drawn, foot soldiers with shields raised above, or protecting from the front. 
By the time the conservation project was assigned to the CCA, in 2007, with financing from the Region of Sardinia and the national Ministry, the rupture between the local community and the institutions was profound. To us this was ideal terrain for organisation of an open worksite. Taking a page from environmental conservation, we used modern communication methods to engage with the Sardinian public, who loved the sculptures, but felt betrayed by the institutions that had kept them in storage for more than 30 years. Planning an open worksite in 2007 wasn't as common as it is today but was accepted by the administrative authority as a public duty.

Since the turn of the century, it's become ever clearer that we've moved on from past traditions, when restoration took place behind closed doors. In 2009, even the New York Public Library showed activities once considered reserved for experts: activities that become material for general curiousity, in part because until now they've been kept backstage. But it has become clear that opening a worksite to the public is not only a matter of piquing curiousity. It's also our opportunity to communicate messages on the value of our cultural heritage.

In the course of the conservation project for the Monte Prama Nuragic sculptures, we organized the workplace in a manner that reproduced the original habitat of the sculptures. In effect, we transformed the laboratory as a museum display. Conservators, curators and restorers need to recognise new cultural behaviours as they develop, and to develop their laboratories in ways that draw attention to cultural heritage, through newly available channels of communication. Museum conservation serves as the springboard to spread the heritage information that today's audiences are seeking. We need to use our activities, and the information we hold, to raise awareness on concepts of fragility and heritage conservation, particularly among younger visitors.

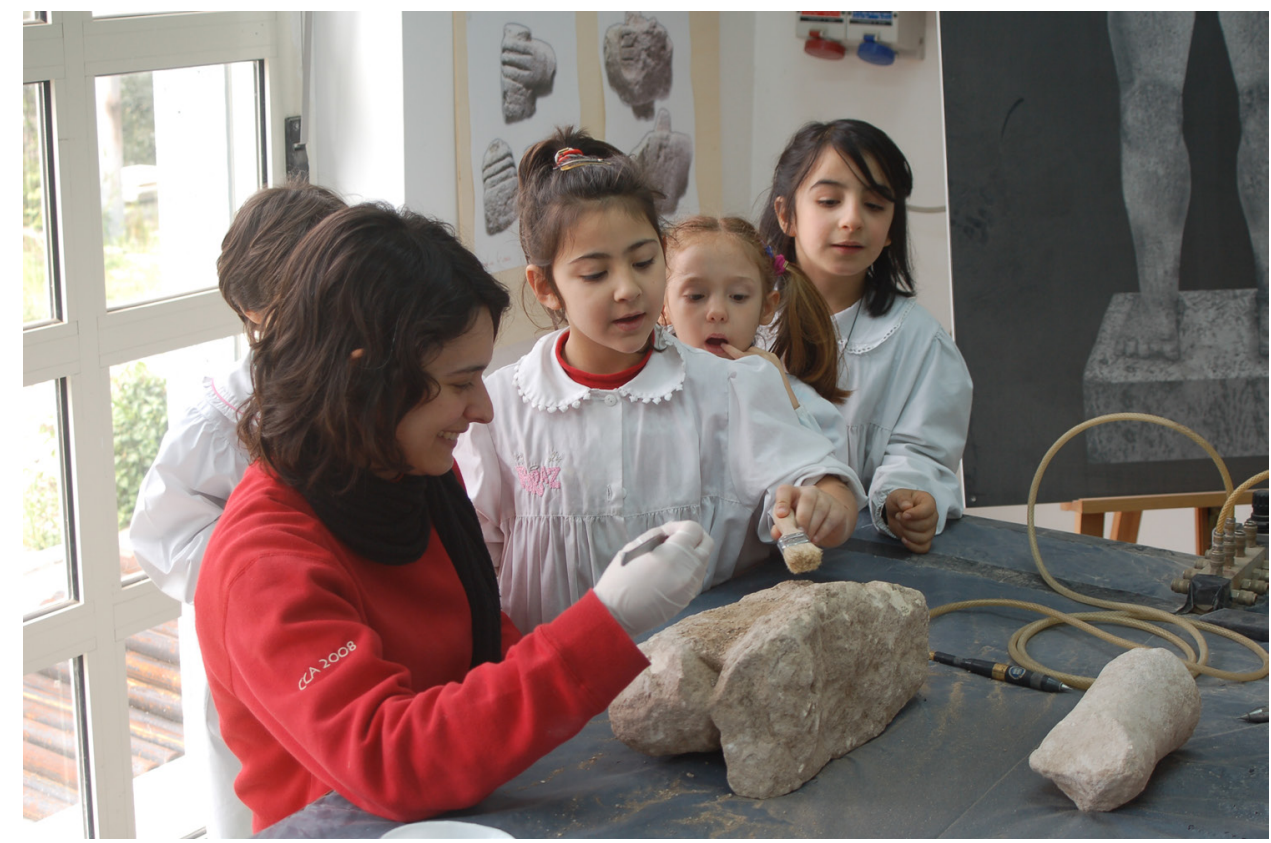

Fig. 8 2007-2011, Interactive visits for children were organized during the conservation project of the Monte Prama sculptures (CCA photo) 
For the Monte Prama project, we organised a series of activities to involve our youngest public: the visiting school groups. One of these was the „Poster I'd Like” competition, for the drawing best communicating the conservation concept. The jury included Gaël de Guichen, adviser to the ICCROM Director General and father of conservation communications.

The Monte Prama project received over fifteen thousand visitors over two years. A thousand of these were school students. Two hundred and fifty participated in the poster competition, and there were twenty-five thousand visits to the Project webpage. The website offered weekly progress reports, and daily counts of the numbers of reassembled fragments, in the Italian, English and Sardinian languages. The laboratory became a leading player in museum outreach. Visitors returned more than once, to follow the progress of the works and research. The webpage followed the work steps, showing: the project poster; press coverage with photographs; the works stages; our technicians' studies with the visiting sculptor, Peter Rockwell; press coverage; school visits; the project pamphlet; our educational materials; the first reconstructed sculpture; the drawing competition; virtual restorations; our survey on the best background for display mounting (Costanzi Cobau, 2014). In fact, what we showed was the many aspects of a fully formed conservation project.

By the time the worksite closed we had raised 38 sculptures to standing position, on stainless steel frameworks, reassembled from 5178 fragments. But the greatest result was having mended the break between community and institutions, thanks to mass-media communications and project participation.

The public opinion developed by our project was fundamental to nomination for the Europa Nostra Awards (European Union Prize for Cultural Heritage), for the best European conservation projects. The CCA project for the Monte Prama sculptures then won the Public Award for 2015.

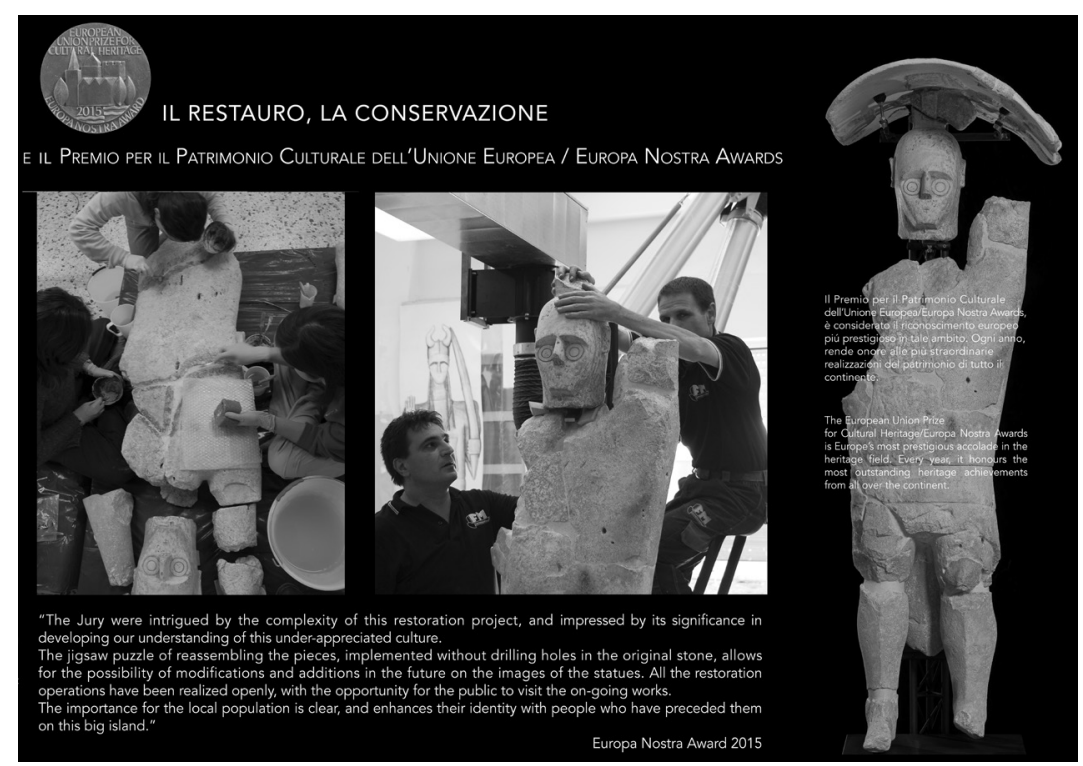

Fig. 9 2015, the project "Nuragic Sculptures of Mont'e Prama" was awarded the European Union Prize for Cultural Heritage / Europa Nostra Awards in the category "conservation". The award is europe's most prestigious accolade in the heritage field. Every yer, it honours the most outstanding heritage achievements from over the continent. Panel in the Museum of Cabras, Sardinia. (CCA photo) 
In that same year we launched a second project stage: changing our dirty t-shirts! I'm joking of course, but seriously, this too enters in communication, and it's fun to design a conservation t-shirt! The real second stage, based on new archaeological discoveries, took place in summer 2015. We transformed the courtyard of the Cabras Civic Museum as our new laboratory. Our courtyard worksite was open to visitors, and one day we had the surprise of seeing one of the sculptures, then under treatment, appear on a visitor's t-shirt! Indeed, the visages of the sculptures, nicknamed The Giants, spread through the civic fabric, speaking with their own voice. The Giants appear in tourism communications, in supermarkets, on wine labels, reaching new levels of stardom. These sculptures are practically snapping their own selfies!

In 2015, the economic facts of the conservation operation were recognised by the business daily, Sole 24 Ore (Cherchi, 2015). The news here was that the Region of Sardinia was sponsoring the A Series basketball team, with the players' uniform bearing an image of a Monte Prama sculptural head. When the team returns from an ,away' win, the fans cheer: „Welcome home Giants”! And the mayor of Cabras, the city where the real stone Giants are on display and where conservation works for new findings continues, has welcomed the team in an official reception. Culture, in the guise of a Nuragic giant, serves as sponsor. And the statistics prove the sponsorship value.

Between 2013 and 2015, visitation at the little Cabras Civic Museum leapt from 9000 to 69,000 visitors, an increase of $740 \%$ in two years. Proof that culture, and conservation, represent economic leverage.

A conservation intervention can transmit important messages. Success depends on careful planning, supported by diversity in the working group. One of the secrets is passion: passion for the material and its communication. And also, a pinch of fantasy, because a masterpiece can be born from each small fragment. All we need to do is discover the right language.

The Monte Prama conservation project functions as a team game, thanks to the archaeologist Antonietta Boninu, heart and soul of the operation. But it takes teamwork to develop a restoration worksite as a cultural event, and it takes planning to give voice to cultural heritage. 


\section{Bibliography}

Cherchi, A. (2015, August, 24). Se lo sponsor è un gigante nuragico. Il Sole 24 Ore, p. 12.

Costanzi Cobau, A. (2014). Le sculture di Monte Prama. Roma: CCA 2014

Nardi, R. (2008). Conservation for presentation: a key for protecting monuments. In: Conservation and Access (pp. 1-5). IIC, London Congress 15-19 sept., 2008. London: IIC

Semeraro, G. (2009). Strumenti tradizionali e nuove tecnologie per la comunicazione. In: archeologia. Archeologia e Calcolatori, 20, pp. 85-94, Lecce.

de Guichen, G. \& Perier d'Ieteren, C. (2009). Raising Awareness for Better Conservation. In: Museum International, Vol. 61, No. 3 UNESCO, pp. 98-105.

ICOM-CC (2008). Terminology to characterize the conservation of tangible cultural heritage. 15th Triennial Conference, 22-26 sept. New Delhi: ICOM-CC.

Tronchetti, C. \& van Dommelen, P. (2005). Entangled objects and hybrid practices: Colonial contacts and elite connections at Monte Prama, Sardinia. In: Journal of Mediterranean Archaeology 18.2, pp. 183-208.

Costanzi Cobau, A. (2003). Il cantiere di restauro aperto al pubblico. In: Aperto per restauro, una parola per..., Roma: Electa.

Pye, E. (2001). Caring for the Past. London: James and James.

La Rocca, E. \& Nardi, R. (1994). Preventive conservation and restoration: a matter of cost. In: Studies in Conservation, 39, Preventive Conservation: Practice, Theory and Research (pp. 24-27).

Nardi, R. (1982-84). L'Arco di Settimio Severo: indagini storiche e conservative. In: Rendiconti della Pontificia Accademia Romana di Archeologia (pp. 299-313), 1982-84, vol. LV-LVI. Roma: Pontificia Accademia Romana di Archeologia. 